\title{
Impact of enteral protein supplementation in premature infants
}

This article was published in the following Dove Press journal:

Research and Reports in Neonatology

7 May 2012

Number of times this article has been viewed

\author{
David M Barrus' \\ Joann Romano-Keeler ${ }^{2}$ \\ Christopher Carr ${ }^{3}$ \\ Kira Segebarth ${ }^{4}$ \\ Betty Claxton ${ }^{2}$ \\ William F Walsh ${ }^{2}$ \\ Paul J Flakoll ${ }^{5}$ \\ 'Department of Neonatology, \\ Saint Francis Hospital-Bartlett, \\ Memphis, TN, ${ }^{2}$ Department \\ of Pediatrics, Vanderbilt Medical \\ Center, Nashville, TN, ${ }^{3}$ Department of \\ Surgery, Naval Hospital Bremerton, \\ Bremerton, WA, ${ }^{4}$ Pediatric and \\ Diabetes Specialists, Carolinas Medical \\ Center, Charlotte, NC, ${ }^{5}$ Department \\ of Surgery, Vanderbilt Medical Center, \\ Nashville, TN, USA
}

Correspondence: Joann Romano-Keeler Monroe Carell Jr Children's Hospital at Vanderbilt, 2200 Children's Way, Nashville, TN 37232, USA

$\mathrm{Tel}+\mathrm{I} 6159368953$

$\mathrm{Fax}+\mathrm{I} 6153431763$

Email joann.romano-keeler@vanderbilt.edu
Objective: The quantity of enteral protein supplementation required by premature infants to optimize growth has not been determined. This study compares the growth of premature infants fed the current standard intake of protein $(3.5 \mathrm{~g} / \mathrm{kg} / \mathrm{day})$ with the growth of those fed a higher amount $(4.0 \mathrm{~g} / \mathrm{kg} /$ day $)$.

Study design: Fifty-two infants $<1500 \mathrm{~g}$ and $<33$ weeks gestational age participated in a blinded, single-center, prospective randomized control trial to compare growth between two groups of different protein-intake levels. Primary outcomes were average daily weight gain ( $\mathrm{g} / \mathrm{kg} /$ day), head-circumference $(\mathrm{cm} / \mathrm{kg} /$ week) and linear growth velocity $(\mathrm{cm} / \mathrm{kg} /$ week). Secondary outcomes were serum indices of protein tolerance and plasma amino acid concentrations.

Results: Infants receiving higher amounts of protein had higher rates of growth for body weight $(18.2 \pm 0.7$ versus $16.2 \pm 1.0 \mathrm{~g} / \mathrm{kg} /$ day; $P<0.05)$ and head circumference $(0.87 \pm 0.08$ versus $0.62 \pm 0.07 \mathrm{~cm} / \mathrm{kg} /$ week; $P<0.05)$, with no differences in blood protein or plasma amino acid concentrations. Length of hospital stay was 14 days shorter for the higher-protein group (51.4 \pm 4.0 versus $65.9 \pm 6.3$ days).

Conclusion: Increasing premature infant enteral protein supplementation from a calculated intake of 3.5-4.0 g/ $\mathrm{kg} /$ day improved growth in a safe manner.

Keywords: human milk, human milk fortifier, growth, low birth weight

\section{Introduction}

The optimal intake of protein and other nutrients by premature infants has been a long-debated topic. The nutritional goal for premature infants is to provide an environment to help them grow at rates comparable to those they would experience in utero. Rarely do premature infants achieve this growth rate during their initial hospital stay. Evaluation of the outcomes of very low birth-weight infants in the National Institute of Child Health and Human Development Neonatal Research Network demonstrated that $79 \%$ of these infants had restricted growth at 36 weeks corrected age. ${ }^{1}$ Early growth deficits have significant implications, as they have been linked to long-term growth failure, including subnormal head circumferences, which often serve as an indirect marker of brain development. This blunted postnatal brain growth has been correlated with poorer neurologic outcomes, including decreased intelligence quotients and adaptive behavior skills. ${ }^{2-4}$

While specific protein requirements for premature infants have not been established in controlled systematic studies, it is clear that preterm human milk provides insufficient ${ }^{5-7}$ and highly variable ${ }^{8}$ quantities of protein to meet the needs of the growing 
preterm infant. Premature infants receiving preterm-infant formula $^{9-11}$ and human milk ${ }^{12,13}$ supplemented with protein were demonstrated to have increased growth versus those fed human breast milk alone. A recent study examining different levels of protein intake in preterm infants found that higher levels of up to $3.3 \mathrm{~g} / \mathrm{kg} /$ day were safe and associated with improved weight gain before initial hospital discharge. ${ }^{14}$ However, balancing the beneficial role of high protein intake with its deleterious effects remains enigmatic. There is no consensus on the optimal daily protein concentration for this at-risk population.

Because the protein content of human milk varies not only between women but also from day to day and even within each feed, a calculated average protein and calorie concentration is used by most studies requiring these values. One of these studies compared growth rates among preterm infants receiving two human milk fortifiers varying in protein content, ${ }^{15}$ and again found the highest rates of growth in those babies receiving the higher protein intake. Because of these results, the current standard of practice at Vanderbilt University Hospital and other hospitals is to feed protein at $3.5 \mathrm{~g} / \mathrm{kg} /$ day.

The objective of this study was to determine the difference in growth rates in premature infants receiving calculated average enteral protein intakes of 3.5 versus $4.0 \mathrm{~g} / \mathrm{kg} /$ day, while varying only the protein intake between the two groups. The primary outcomes followed were measurements of growth, including weight, length and head circumference. Secondary outcomes were measurements of morbidity and blood markers of protein tolerance.

\section{Materials and methods Subjects}

Approval for this study was obtained from Vanderbilt University's Institutional Review Board. Babies were eligible for this study if their birth weights were less than $1500 \mathrm{~g}$ and gestational ages were less than 33 weeks. In addition, they were required to be free from growth-affecting anomalies, including gastrointestinal malformations, necrotizing enterocolitis, cardiac disorders excluding a history of patent ductus arteriosus and hydrocephalus requiring shunting. Participation was restricted to those babies whose feedings were initially breast milk. For this single-center study, 60 qualified babies were identified, parental consent was obtained and their assigned protein-intake regimen was initiated when each baby reached full-volume feeds (130-150 mL/kg/day), as determined by their medical team, and completed all parenteral protein supplementation. Babies completed the study when they reached $1800 \mathrm{~g}$ or when they were discharged home or to an affiliated hospital. Babies were withdrawn from the study early if they were unable to continue feeds totaling at least $100 \mathrm{~mL} / \mathrm{kg}$ /day for 72 hours. It was determined a priori that babies participating in the study for less than 8 days would not be included in the final data analysis.

\section{Design}

This study was a blinded, prospective randomized control trial comparing growth rates of preterm infants receiving enteral protein intakes calculated to be 3.5 versus $4.0 \mathrm{~g} / \mathrm{kg} /$ day. Breast-milk feedings fortified to $3.5 \mathrm{~g} / \mathrm{kg} /$ day were prepared by mixing four packets of human milk fortifier (Similac HMF; Ross Laboratories, Columbus, $\mathrm{OH}$ ) and $0.5 \mathrm{~g} / \mathrm{kg} / \mathrm{day}$ of powdered modular protein supplement (ProMod; Abbott Laboratories Ross Products Division, Columbus, $\mathrm{OH}$ ) with $100 \mathrm{~mL}$ of breast milk. Those fortified to $4.0 \mathrm{~g} / \mathrm{kg} / \mathrm{day}$ were prepared by mixing four packets of HMF and $1.0 \mathrm{~g} / \mathrm{kg} /$ day of powdered modular protein supplement of ProMod with $100 \mathrm{~mL}$ of breast milk. The quantity of modular protein added to each group's feeds was dependent upon the daily volume intake to ensure the protein intake remained consistent with a baby's assigned intake group. The supplements were premeasured daily for each specific baby and placed in coded containers at the bedside to be mixed with their feeds. Differences between groups' coded tubes were not discernible to the naked eye. If breast milk was not available for a feed, a standard premature-infant formula (Similac Special Care 24; Abbott Laboratories Ross Products Division) was supplemented to the appropriate protein levels of 3.5 and $4.0 \mathrm{~g} / \mathrm{kg} /$ day with modular protein of 0.5 and $1.0 \mathrm{~g} / \mathrm{kg} /$ day, respectively.

There were three principal investigators involved with randomization of patients. Prior to the initiation of the study, a set of opaque envelopes was created with patient assignments as control or treatment. These envelopes were opened by the study nutritionist, who prepared the appropriate formula for the patient with the hospital nutrition team. The study nutritionist provided feedings in coded tubes to the three principal investigators, who were responsible for distributing them to the patients' bedside nurses. These bedside nurses were also blinded to the patients' assignments to low- or high-protein intake.

\section{Measurements}

The primary outcome measured was infant growth. Daily body weight estimated to the nearest gram and weekly head circumference to the nearest $0.25 \mathrm{~cm}$ were measured by 
trained neonatal bedside nurses as per the unit's standardized protocol. They also recorded weekly recumbent length, measured to the nearest $0.25 \mathrm{~cm}$ with a nonstretchable tape. Growth rates for each infant were calculated using that infant's average measurement for that parameter. Serum was analyzed from blood collected by venous puncture upon entry into the study and biweekly thereafter. The serum indices measured were total protein, albumin, $\mathrm{pH}$, hematocrit and blood urea nitrogen by the Vanderbilt University Hospital laboratory. Plasma amino acid concentrations were determined by reversed-phase high-performance liquid chromatography after derivatization with phenylisothiocynate ${ }^{16}$ in the investigators' laboratory.

\section{Sample size calculations and statistical methods}

We considered a $10 \%$ difference in growth rates, including linear and head-circumference velocity as well as average daily weight gain, between the two groups as clinically significant. To identify a difference of this size with respect to all three growth parameters between the low- and highprotein group, we required a sample size of 30 babies per intake group, based on a standard deviation of $13.5 \%$ and our power calculations ( 0.05 for type I error probability and 0.80 for power). Data analysis consisted of a comparison of an experimental (high protein intake) versus a control (standard protein intake) group using an analysis of variance

Table I Initial study population measurements

\begin{tabular}{lll}
\hline & Control & Experimental \\
\hline $\mathrm{n}$ & 26 & 26 \\
Gestational age (weeks) & $27.9 \pm 0.4$ & $27.8 \pm 0.3$ \\
Birth weight (g) & $1008 \pm 43$ & $1062 \pm 42$ \\
Number of IUGR infants & $\mathrm{I}$ & $\mathrm{I}$ \\
Sex (M:F) & $16: 10$ & $7: 19 *$ \\
Race & & \\
$\quad$ Non-Hispanic white & 17 & 20 \\
$\quad$ African-American & 5 & 5 \\
$\quad$ Hispanic & 4 & 1 \\
Median I-minute Apgar & 7 & 5 \\
(25th, 75th percentile) & $(3,8)$ & $(2,6)$ \\
Median 5-minute Apgar & 7 & 7 \\
(25th, 75th percentile) & $(6,8)$ & $(5,8)$ \\
Days to first feed & $2.9 \pm 0.4$ & $3.5 \pm 0.6$ \\
Days to I00 mL/kg/day & $20.1 \pm 10.7$ & $15.2 \pm 6.7$ \\
Weight at day 0 & $1224 \pm 42$ & $1203 \pm 40$ \\
Days on study & $20.4 \pm 2.1$ & $19.4 \pm 2.0$ \\
Patients on ventilator & 18 & 18 \\
Days on ventilator & $9.7 \pm 3.0$ & $5.6 \pm 1.9$ \\
\hline Note: & &
\end{tabular}

Note: $* P<0.05$ difference from $3.5 \mathrm{~g} / \mathrm{kg} /$ day group. Abbreviation: IUGR, intrauterine growth restriction.
Table 2 Reasons for infant intolerance to feeding (number of infants)

\begin{tabular}{lll}
\hline Condition & Control & Experimental \\
\hline Necrotizing enterocolitis & 2 & 0 \\
Septic ileus & $\mathrm{I}$ & $\mathrm{I}$ \\
Other ileus & 0 & $\mathrm{I}$ \\
\hline
\end{tabular}

and a Student's $t$-test with the Statistical Analysis System (SAS Institute, Cary, NC). Differences between the treatment groups for gender and race were assessed using chisquared analysis (SAS). Statistical significance level was set at $P<0.05$. Values presented in the text and tables are means \pm structural equation modeling.

\section{Results Subjects}

Sixty patients were recruited for the study, 30 per treatment group. Initial measurements from the study population are included in Table 1. The range in birth weight was 550-1475 $\mathrm{g}$ in the control group and 620-1369 $\mathrm{g}$ in the experimental group. Infants of multiple births were randomized separately, and the mean number of offspring at parity was not different. There was a difference in gender composition between groups, with the control group having more males and the experimental group having more females. Four babies from each treatment group were on treatment less than 8 days and were excluded from data analysis. Though five of the 52 participants had a 72-hour period of feeding intolerance at volumes of $100 \mathrm{~mL} / \mathrm{kg} /$ day, all five of them were still included in the study, since they had already completed at least 8 days on the studyfeeding protocols. The reasons for intolerance are shown in Table 2.

\section{Growth}

Rates of growth are included in Table 3 . The rate of weight gain $(\mathrm{g} / \mathrm{kg} /$ day) was $12 \%$ higher, and head-circumference gain was $40 \%$ higher for the experimental group. Longitudinal growth rate $(\mathrm{cm} / \mathrm{kg} /$ week) was $15 \%$ greater in the group receiving the higher protein, but this was not statistically significant.

Table 3 Growth rates

\begin{tabular}{lll}
\hline & Control & Experimental \\
\hline Weight $(\mathrm{g} / \mathrm{kg} / \mathrm{day})$ & $16.2 \pm 1.0$ & $18.2 \pm 0.7^{*}$ \\
Length $(\mathrm{cm} / \mathrm{kg} /$ week) & $0.92 \pm 0.14$ & $1.06 \pm 0.13$ \\
Head circumference $(\mathrm{cm} / \mathrm{kg} /$ week) & $0.62 \pm 0.07$ & $0.87 \pm 0.08^{*}$ \\
\hline
\end{tabular}

Note: $* p<0.05$ difference from $3.5 \mathrm{~g} / \mathrm{kg} /$ day group. 
Table 4 Nutritional intake and days hospitalized

\begin{tabular}{lll}
\hline & Control & Experimental \\
\hline Volume intake $(\mathrm{mL} / \mathrm{kg} /$ day) & $140.2 \pm 3.0$ & $140.4 \pm 2.7$ \\
\% Breast milk & $51.6 \pm 8.3$ & $69.7 \pm 7.3^{*}$ \\
(average \% breast milk/day) & & \\
$\begin{array}{l}\text { Days nil per oral per infant } \\
\text { Hospitalization (days) }\end{array}$ & 0.12 & 0.31 \\
\hline
\end{tabular}

Note: $* P<0.05$ difference from $3.5 \mathrm{~g} / \mathrm{kg} /$ day group.

\section{Nutrient intake and days hospitalized}

Volume intake, caloric density and caloric intake were similar between groups (Table 4). The experimental group tended to have more of their total-volume intake in the form of breast milk. The total days hospitalized were $22 \%$ less (14 days) in the group receiving the higher-protein intake.

\section{Blood measurements}

Baseline and subsequent laboratory values were measured to evaluate the safety of the two protein intakes and are displayed in Tables 5 and 6 . None of the values differed between intake groups. Plasma amino acid concentrations, either individually or grouped as branched-chain amino acids, essential amino acids, nonessential amino acids or total amino acids were not different with increased protein intake.

Table 5 Serum indices

\begin{tabular}{|c|c|c|}
\hline & Control & Experimental \\
\hline \multicolumn{3}{|c|}{ Blood urea nitrogen } \\
\hline \multicolumn{3}{|c|}{$(\mathrm{mmol} / \mathrm{L}(\mathrm{mg} / \mathrm{dL}))$} \\
\hline Day 0 & $3.53 \pm 0.39(9.9 \pm 1.1)$ & $3.39 \pm 0.32(9.5 \pm 0.9)$ \\
\hline Day 14 & $2.00 \pm 0.32(5.6 \pm 0.9)$ & $2.61 \pm 0.25(7.3 \pm 0.7)$ \\
\hline \multicolumn{3}{|c|}{ Total serum protein } \\
\hline$(\mathrm{g} / \mathrm{L}(\mathrm{g} / \mathrm{dL}))$ & $5 I \pm I .0(5 . I \pm 0 . I)$ & $49 \pm 1.0(4.9 \pm 0.1)$ \\
\hline Day 14 & $48 \pm 1.0(4.8 \pm 0.1)$ & $46 \pm 1.0(4.6 \pm 0.1)$ \\
\hline \multicolumn{3}{|l|}{ Albumin } \\
\hline \multicolumn{3}{|l|}{$(g / L(g / d L))$} \\
\hline Day 0 & $28 \pm 1.0(2.8 \pm 0.1)$ & $28 \pm 1.0(2.8 \pm 0.1)$ \\
\hline Day 14 & $26 \pm 1.0(2.6 \pm 0.1)$ & $25 \pm 1.0(2.5 \pm 0.1)$ \\
\hline \multicolumn{3}{|l|}{$\mathrm{pH}$} \\
\hline Day 0 & $7.38 \pm 0.01$ & $7.35 \pm 0.01$ \\
\hline Day 14 & $7.38 \pm 0.01$ & $7.36 \pm 0.02$ \\
\hline \multicolumn{3}{|c|}{$\mathrm{pCO}_{2}(\mathrm{~mm} \mathrm{Hg})$} \\
\hline Day 0 & $47.2 \pm 2.2$ & $48.1 \pm 2.2$ \\
\hline Day 14 & $46.6 \pm 2.7$ & $49.6 \pm 3.4$ \\
\hline \multicolumn{3}{|c|}{ Hematocrit (\%) } \\
\hline Day 0 & $38.1 \pm 0.9$ & $37.1 \pm 1.2$ \\
\hline Day 14 & $32.7 \pm 1.0$ & $32.5 \pm 1.2$ \\
\hline
\end{tabular}

Note: There were no significant differences between protein-intake groups for any of these variables at either week I or 3 .
Table 6 Plasma amino acid concentrations ( $\mu \mathrm{mol} / \mathrm{L})$

\begin{tabular}{|c|c|c|}
\hline & Control & Experimental \\
\hline I-Methylhistidine & $0.3 \pm 0.3$ & $0.5 \pm 0.3$ \\
\hline 3-Methylhistidine & $3.2 \pm 0.6$ & $5.0 \pm 1.1$ \\
\hline Alanine & $682 \pm 88$ & $613 \pm 78$ \\
\hline Arginine & $10.1 \pm 1.4$ & $16.1 \pm 4.8$ \\
\hline Asparagine & $58.4 \pm 5.1$ & $63.6 \pm 6.3$ \\
\hline Aspartate & $62.2 \pm 6.6$ & $57.2 \pm 6.4$ \\
\hline Citrulline & $31.2 \pm 3.3$ & $30.6 \pm 3.3$ \\
\hline Glutamate & $184 \pm 35$ & $213 \pm 47$ \\
\hline Glutamine & $383 \pm 44$ & $371 \pm 38$ \\
\hline Glycine & $434 \pm 39$ & $4 I I \pm 34$ \\
\hline Histidine & $67.5 \pm 6.3$ & $61.9 \pm 5.6$ \\
\hline Hydroxyproline & $107.6 \pm 7.6$ & $108.8 \pm 6.8$ \\
\hline Isoleucine & $42.4 \pm 3.1$ & $45.6 \pm 4.1$ \\
\hline Leucine & $85.3 \pm 4.3$ & $85.6 \pm 5.8$ \\
\hline Lysine & $202 \pm 14$ & $195 \pm 19$ \\
\hline Methionine & $28.7 \pm 1.8$ & $31.4 \pm 1.2$ \\
\hline Ornithine & $197 \pm 22$ & $168 \pm 19$ \\
\hline Phenylalanine & $46.6 \pm 3.7$ & $47.5 \pm 2.7$ \\
\hline Proline & $252 \pm 15$ & $257 \pm 21$ \\
\hline Serine & $252 \pm 30$ & $224 \pm 29$ \\
\hline Taurine & $317 \pm 26$ & $288 \pm 29$ \\
\hline Threonine & $223 \pm 22$ & $223 \pm 25$ \\
\hline Tryptophan & $28.9 \pm 1.9$ & $25.4 \pm 2.4$ \\
\hline Tyrosine & $119 \pm 14$ & $107 \pm 12$ \\
\hline Valine & $|3| \pm 7$ & $|3| \pm 1 \mid$ \\
\hline Branched chain & $259 \pm 13$ & $262 \pm 19$ \\
\hline Essential & $865 \pm 47$ & $86 I \pm 6 I$ \\
\hline Nonessential & $3056 \pm 220$ & $2895 \pm 214$ \\
\hline Total & $3920 \pm 259$ & $3756 \pm 258$ \\
\hline
\end{tabular}

Notes: Values $(\mu \mathrm{mol} / \mathrm{L})$ are reported as the mean \pm structural equation modeling for each group. Blood samples in the infants were taken 7-10 days after initiation of the experiment. There were no differences between the two groups of infants.

\section{Discussion}

It has been shown that protein supplementation of preterm breast milk results in improved growth in premature infants. The optimal quantity of protein supplementation in preterm infants, however, has not been defined. Based upon recent data, several neonatal care units have used a calculated protein intake of $3.5 \mathrm{gm} / \mathrm{kg} / \mathrm{day}$ as the standard of care for this population.

The present study compared the standard protein intake with a higher calculated intake of $4 \mathrm{gm} / \mathrm{kg} /$ day and found that all parameters of growth measured were improved with the increased protein intake. Although these rates of growth are still slightly below that previously found in utero, ${ }^{17}$ the increased growth was of a magnitude that was both statistically and clinically significant (except length). Importantly, 

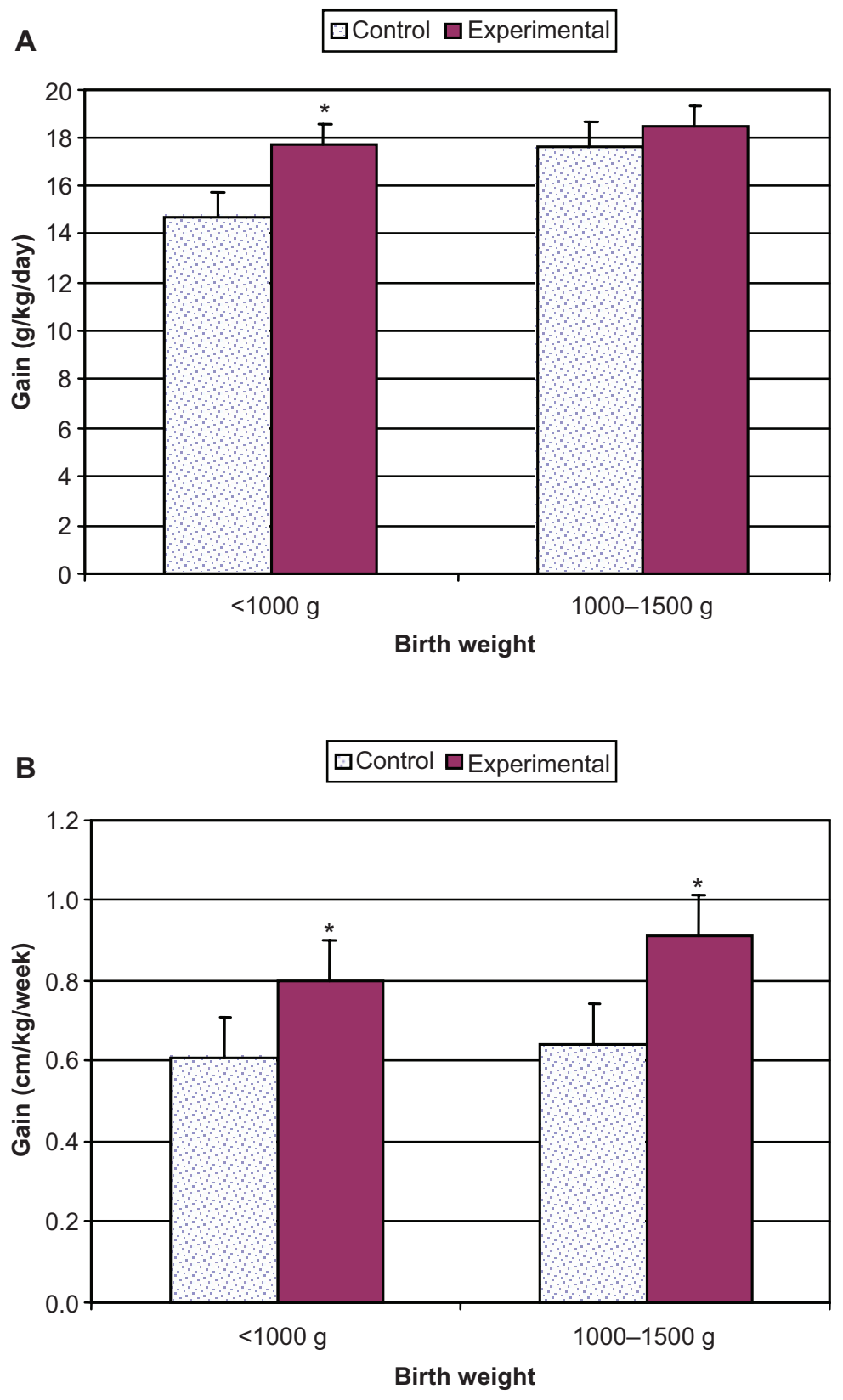

\begin{tabular}{|l|l|l|}
\hline & Control & Experimental \\
\hline 1000 & 13 & 10 \\
\hline $1001-1500$ & 13 & 16 \\
\hline
\end{tabular}

Figure I The interaction of birth weights with daily body-weight $(\mathbf{A})$ and head-circumference $(\mathbf{B})$ growth rates. Babies with birth weights less than I000 g are included on the left, and babies with birth weights between 1000 and $1500 \mathrm{~g}$ are included on the right.

Notes: $* P<0.05$ difference from $3.5 \mathrm{~g} / \mathrm{kg} /$ day group within the same birth-weight range. Usual custom is $1000 \mathrm{~g}$ or less and $100 \mathrm{I}-1500 \mathrm{~g}$.

the increase in growth was obtained without increasing infant morbidity or mortality. Furthermore, the period of hospitalization in this study was reduced by about 14 days with the higher protein, which would have considerable economic impact.
It was interesting that an increase in protein intake by $0.5 \mathrm{~g} / \mathrm{kg} /$ day led to an increase in body weight of $2 \mathrm{~g} / \mathrm{kg} /$ day. Olsen et a ${ }^{18}$ reported comparable accelerated growth velocities of greater than $4 \mathrm{~g} / \mathrm{kg} /$ day with an additional $1 \mathrm{~g} / \mathrm{kg} /$ day of protein. Studies of protein kinetics in 
preterm infants ${ }^{19}$ have demonstrated that nitrogen balance improves linearly during incremental increases in protein intake from 0.8 to $3.5 \mathrm{~g} / \mathrm{kg} /$ day. ${ }^{19}$ Furthermore, rates of flux or oxidation for marker amino acids are unaffected by these increases in protein intake, indicative of the continued ability of these infants to metabolize a higher protein load. Taken together, the linearity of these data suggests that the optimal intake of protein may likely be greater than $3.5 \mathrm{~g} / \mathrm{kg} /$ day.

It is possible that protein requirements may be different at each stage of growth. While this study was not designed with the power to address this question, some insight can be gained from these data. When body-weight and headcircumference growth data are grouped according to ranges in birth weight (Figure 1A and B), it is interesting to note that the differences in body-weight gain between the 3.5 and $4.0 \mathrm{~g} / \mathrm{kg} /$ day protein intake were greater in the infants with birth weights less than $1000 \mathrm{~g}$ (20\% increase), as opposed to the infants with birth weights between 1000 and $1500 \mathrm{~g}$ ( $5 \%$ increase). While more research is needed, this would suggest that the lower-birth-weight infants may have greater protein intake requirements.

Two factors that did differ between the two groups were the infants' gender and the amount of breast milk received. Previous research has shown that (1) preterm male infants had higher growth rates than females, ${ }^{21}$ and (2) infants fed breast milk grew more slowly than infants fed formula. ${ }^{10}$ Therefore, consideration of these variables would suggest that this study provides a conservative estimate of the effects of protein supplementation, and the increases noted may have been larger if gender and amount of breast milk received were equivalent. A limitation of this study includes the lack of adjustment for multiple comparisons, despite the different outcomes that were analyzed. Inclusion of these adjustments would have diminished the statistical significance of our results, though omission may have increased the probability of false positives.

In conclusion, increased calculated protein intake in premature infants from 3.5 to $4.0 \mathrm{~g} / \mathrm{kg} /$ day resulted in clinical improvements in growth without changes in morbidity or mortality. The benefits and safety of protein intakes greater than $4.0 \mathrm{~g} / \mathrm{kg} /$ day are still unclear. The results of this study may lead to additional research that would allow us to define the optimal level of protein intake and its importance in this at-risk population. Finally, a better understanding of the relationship between increased growth as a result of increased protein intake and long-term cognitive development would help our understanding of the importance of these findings.

\section{Acknowledgments}

The authors would like to express their appreciation to the subjects and their families. Support from the State of Tennessee, the Vanderbilt Department of Surgery and a neonatal training grant provided by the National Institutes of Health awarded to Dr Barrus were greatly appreciated. The study would not have been possible without the excellent assistance from the neonatal intensive care unit staff and the Vanderbilt Pharmacy. The excellent technical and laboratory assistance of Suzan Vaughan, Jennifer Young and Hannah Vaughan were sincerely appreciated. Finally, this article is dedicated to the memory of Dr Flakoll, who was instrumental to this study.

\section{Disclosure}

The authors report no conflicts of interest in this work.

\section{References}

1. Stoll BJ, Hansen NI, Bell EF, et al. Neonatal outcomes of extremely preterm infants from the National Institute of Child Health and Human Development Neonatal Research Network. Pediatrics. 2010;126: 443-456.

2. Lucas A, Morley R, Cole TJ. Randomized trial of early diet in preterm babies and later intelligence quotient. BMJ. 1998;317:1481-1487.

3. Hack M, Breslau N, Weissman B, Aram D, Klein N, Borawski E. Effect of very low birth weight and subnormal head size on cognitive abilities at school age. N Engl J Med. 1991;325:231-237.

4. Peterson J, Taylor HG, Minich N, Klein N, Hack M. Subnormal head circumferences in very low birth weight children: neonatal correlates and school-age consequences. Early Human Dev. 2006;82: 325-334.

5. Davies DP. Adequacy of expressed breast milk for early growth of preterm infants. Arch Dis Child. 1977;52:296-301.

6. Fomon SJ, Ziegler EE, Vazquez HD. Human milk and the small premature infant. Am J Dis Child. 1977;131:463-467.

7. Forbes GB. Nutritional adequacy of human milk for prematurely born infants. In: Lebenthal E, editor. Textbook of Gastroenterology and Nutrition in Infancy. New York: Raven; 1989:27-34.

8. Weber A, Loui A, Jochum F, Buhrer C, Obladen M. Breast milk from mothers of low birthweight infants: variability in fat and protein content. Acta Paediatr. 2001;90:772-775.

9. Brooke OG, Onubogu O, Heath R, Carter ND. Human milk and preterm formula compared for effects on growth and metabolism. Arch Dis Child. 1987;62:917-923.

10. Schanler RJ, Shulman RJ, Lau C. Feeding strategies for premature infants: beneficial outcomes of feeding fortified human milk versus preterm formula. Pediatrics. 1999;103:1150-1157.

11. Akeson PMK, Axelsson I, Raiha NC. Growth and nutrient intake in three- to twelve-month-old infants fed human milk or formulas with varying protein concentration. J Pediatr Gastroenterol Nutr. 1998;26:1-8.

12. Arslanoglu S, Moro GE, Ziegler EE. Adjustable fortification of human milk fed to preterm infants: does it make a difference? J Perinatol. 2006;26;614-621.

13. Heinrikson R, Arslanoglu S, Moro GE, Ziegler EE. Preterm infants fed fortified milk receive less protein than they need. J Perinatol. 2009;7:489-492.

14. Embleton N, Cooke R. Protein requirements in preterm infants: effect of different levels of protein intake on growth and body composition. Pediatr Res. 2005;58:855-860. 
15. Reis BB, Hall RT, Schanler RJ, et al. Enhanced growth of preterm infants fed a new powdered human milk fortifier: a randomized, controlled trial. Pediatrics. 2000;106:581-588.

16. Heinrikson R, Meredith SC. Amino acid analysis by reverse-phase HPLC: pre-column derivatization with phenylisothiocyanate. Anal Biochem. 1984;136:65-74

17. Ziegler EE, O'Donnell AM, Nelson SE, Fomon SJ. Body composition of the reference fetus. Growth. 1976;40:329-341.

18. Olsen IE, Richardson DK, Schmid CH, Ausman LM, Dwyer JT. Intersite differences in weight growth velocity of extremely premature infants. Pediatrics. 2002;110:1125-1132.
19. Zello GA, Menendez CE, Rafii M, et al. Minimum protein intake for the preterm neonate determined by protein and amino acid kinetics. Pediatr Res. 2003;53:338-344.

20. Cooke RJ, Embleton N, Rigo, J, Annelise, C, Haschke, F, Ziegler, E. High protein preterm infant formula: effect on nutrient balance, metabolic status, and growth. Pediatr Res. 2006;59:265-270.

21. Cox WM, Filer LJ. Protein intake for low-birth-weight infants. J Pediatr. 1969;74:1016-1020.

Research and Reports in Neonatology

Dovepress

\section{Publish your work in this journal}

Research and Reports in Neonatology is an international, peer-reviewed, open access journal publishing original research, reports, editorials, reviews and commentaries on neonatal health. The manuscript management system is completely online and includes a very quick and fair

peer-review system. Visit http://www.dovepress.com/testimonials.php to read real quotes from published authors. 